\title{
Plant, tuber and seed properties of Himantoglossum robertianum (Loisel.) P. Delforge and Orchis italica Poiret
}

\author{
Himantoglossum robertianum (Loisel.) P. Delforge (Patpatanak) ve Orchis italica \\ Poiret'in (Tavşan topuğu) bitki, yumru ve tohum özellikleri
}

\section{Salih PARLAK ${ }^{1}$}

${ }^{1}$ Bursa Teknik Üniversitesi, Orman Fakültesi, Bursa

Sorumlu yazar (Corresponding author) Salih PARLAK

salih.parlak@btu.edu.tr

Geliş tarihi (Received)

28.02.2021

Kabul Tarihi (Accepted)

02.11.2021

Sorumlu editör (Corresponding editor) Gaye KANDEMİR

gayeeren@gmail.com

Atıf (To cite this article): Parlak, S. (2022). Plant, tuber and seed properties of Himantoglossum robertianum (Loisel.) P. Delforge and Orchis italica poiret . Ormancılık Araştırma Dergisi , 9 (1) , 7080 . DOI: $10.17568 /$ ogmoad. 888114

\begin{abstract}
Although orchids are the most rich family of the plant kingdom, they make up the most destroyed group. Due to human impact, environmental factors, tourism and settlement, ornamental plants or food collection, the spread areas are getting narrower and endangered every day. Two of these endangered species due to their use in the food industry are Himantoglossum robertianum (Loisel.) P. Delforge and Orchis italica Poiret. Both of these sahlep orchids taxa are preferred by collectors in terms of their tuber size and the glucomannan contains and are heavily destroyed. Excessive destruction brings some pollination and fertilization problems. Orchid seeds do not have an endosperm and need a symbiotic relationship to germinate. To germinate in an asymbiotic environment, it is necessary to apply the seeds that break dormancy and keep them in a special medium and environment. The structure of the seed coat is important in eliminating the germination barrier in asymbiotic production. In this study tuber and seed morphological and physiological properties of both species were determined. Morphological features such as plant height, tuber weight and dimensions, seed sizes, seed weight, the number of seeds in $1 \mathrm{~g}$, and physiological features such as seed moisture, shell structure and fullness of seeds were determined. The causes of empty seed formation are interpreted in light of the literature.
\end{abstract}

Keywords: Himantoglossum robertianum, Orchis italica, tuber, seed caracteristics

\section{Öz}

Orkideler, bitkiler aleminin en zengin ailesi olmasına rağmen en çok tahrip edilen grubu oluşturur. İnsan etkisi, çevresel faktörler, turizm ve yerleşim, süs bitkisi veya yiyecek olarak kullanım nedeniyle yayılış alanları her geçen gün daralmakta ve tehlike altına girmektedir. Gıda endüstrisinde kullanımı ve aşırı toplama nedeniyle nesli tükenmekte olan bu türlerden ikisi Himantoglossum robertianum (Loisel.) P. Delforge ve Orchis italica Poiret'tir. Her iki sahlep orkidesi de yumru iriliği ve glukomannan içeriği bakımından toplayıcılar tarafından tercih edilmekte ve ağır şekilde tahribata uğramaktadır. Aşırı tahribat bazı tozlaşma ve döllenme sorunlarını da beraberinde getirmektedir. Orkide tohumlarında endosperm olmadığından çimlendikten sonra su ve besin alabilmek için mikorizalar ile simbiyotik ilişkiye ihtiyaç duyarlar. Asimbiyotik ortamda çimlendirebilmek için tohumlarda dormansinin (çimlenme engelinin) kırılması, özel beslenme ortamı ve çevre şartlarının sağlanması gerekir. Asimbiyotik ortamda tohumun çimlendirilmesinde embriyoyu saran kabuk yapısının da etkisi bulunmaktadır. Bu çalışmada her iki türün yumru ve tohumlarının morfolojik ve fizyolojik özellikleri belirlenmiştir. Bitki boyu, yumru ağırlığ 1 ve boyutları, tohum boyutları, tohum ağırlığı, 1 g'daki tohum sayısı gibi morfolojik özellikler ile tohum nemi, kabuk yapısı ve tohum doluluğu gibi fizyolojik özellikler belirlenmiştir. Boş tohum oluşumları literatür bilgileri ile değerlendirilmiştir.

Anahtar Kelimeler: Himantoglossum robertianum, Orchis italica, yumru, tohum özellikleri 


\section{Introduction}

The orchids with 25000 to 30000 species in some 700 to 800 genera constitute the largest family among flowering plants (De et al., 2014). Orchids produce large amounts of seeds, and each capsule can contain up to four million seeds. The seeds are very minute and range in length from 0.05 to $6 \mathrm{~mm}$, 0.01 to $0.93 \mathrm{~mm}$ in width, and weigh 0.31 to $24 \mu \mathrm{g}$ (Arditti, 1967; Arditti and Ghani, 2000). Another feature of orchid seeds is that they adapt to wind dispersal (Baskin and Baskin, 2014). In addition to their low mass, seeds also have a high seed/embryo volume ratio. The embryo occupies only a minor proportion of the volume inside the testa (Weston et al., 2005).Thus, orchid seeds are very buoyant and can float on the surface of water or be carried by wind (Arditti and Ghani, 2000; Baskin and Baskin, 2014).

Although there are millions of seeds in a capsule, only $0.2 \%-0.3 \%$ of them can germinate seeds in nature, hence the quantity is limited (Doijode, 2001). They have some characteristics, such as reduced embryo and the absence of endosperm (Johri, 1985). Orchids seeds contain few nutrient reserves and may have morphological and morphophysiological dormancy, often imposing a low germination percentage. Therefore, in natural conditions, few seeds successfully germinate because of the lack of both an endosperm. They must be in a symbiotic relationship with fungi for germination (Veyret, 1974; Maheshwari, 2005; Baskin and Baskin, 2014). The epiphytic species germinate better than the terrestrial ones due probably to their simpler nutritional requirements (Arditti et al., 1982; Rasmussen, 1995; Miyoshi and Mii, 1998).

Another factor affecting germination of orchids is the morphological dormancy of the seed crust. One of the most important exogenous seed dormancy barriers is the hydrophobic nature of the seed coat that surrounds the embryo. (Weston et al., 2005) Seed coat is sclerotic (phenolic compounds, cutin, suberin, lignin) (Slaviero, 2016). Treatments, such as hypochlorite soaks, can be used to weaken the testa, improve permeability, and promote germination. These treatments are often used to bypass physiological or physical dormancy (Dutra et al, 2008).

$H$. robertianum and $O$. italica are the most destroyed species for the production of sahlep. The characteristics of the species are also effective in this destruction. Plants are easy to see and valuable species for the production of sahlep attracts collectors. The height of the plant varies between 20-80 $\mathrm{cm}$. (Davis, 1984). Findings had the advantage of the plant height and attractiveness, with stems up to $100 \mathrm{~cm}$, together to an early flowering (February to April), which made the plant easily recognizable (Aedo and Herrero, 1986). Furthermore, the tubers of these species are larger than other species and have better glucomannan ratios (Tekinşen and Güner, 2009) and more easily detected at this time and tubers are in a better condition (Sezik, 2002; Molnár et al., 2017). Molnár et al., (2017) found a significant relationship between tuber size and harvesting frequency, which suggests that species with large tubers might be at a higher risk of being harvested. $H$. robertanum ranks first with a frequency of $39.5 \%$ in wild collection. Because of this unequal harvesting, early flowering taxa are probably at a higher risk from sahlep collection than late flowering ones.

$H$. robertianum and $O$. italica have been over-harvested because of increasing demand in the market. The threat is further exaggerated due to destruction of its natural habitats. Therefore, it is important to establish an efficient regeneration and multiplication system for the production of plantlets (Molnár et al., 2017). In vitro germination of orchid seeds vary according to the morphological and physiological characteristics of the orchid species. Orchid seed coats are only one cell thick and lack the water-impermeable palisade layers characteristic of seeds with physical dormancy (Baskin and Baskin, 2014). The removal of dormancy barrier depends on the testa structure of the species. Scientific studies on seed weight and especially empty seed formation are insufficient. Therefore in this study, it is aimed to reveal $O$. italica and $H$. robertianum seeds and tuber characteristics.

\section{Material and methods}

\subsection{Material}

Seeds of $H$. robertianum and $O$. italica were donated by Agricultural Research Institute in Menemen, İzmir, Turkey. Seeds were collected in the spring 2019 from open-pollinated plants.

In the counting of seeds, Stereo Microscope (Irmeco, IM SZ550-B-ST5-H, Geesthacht/Germany), four-digit digital precision scales (Radwag, AS 220. R2- Radom/Poland) for weighing (Radwag MA 50.R- Radom/Poland) device, Scanning Electron Microscope (SEM) (Carl Zeiss/Gemini 300-Jena/ Germany) and hydrogen peroxide (sigma-Aldrich, $34.5-36.5 \%$ ) were used.

\subsection{Methods}

\subsubsection{Extraction and storage of seeds}

Seeds were taken at full ripening time and without opening the capsules. The capsules were dried and 
taken in a controlled way. Seeds were placed in Eppendorf tubes and stored at $+4^{\circ} \mathrm{C}$ until working.

\subsubsection{Seed characteristics and seed count}

To determine the number of seeds in $1 \mathrm{~g}$, the seeds of both species were weighed on a four-digit scale. Terrestrial orchid seeds are very minute (200 to $1700 \mu \mathrm{m})$ and distinguish viability of seeds were very difficult to determine using triphenyl tetrazo-

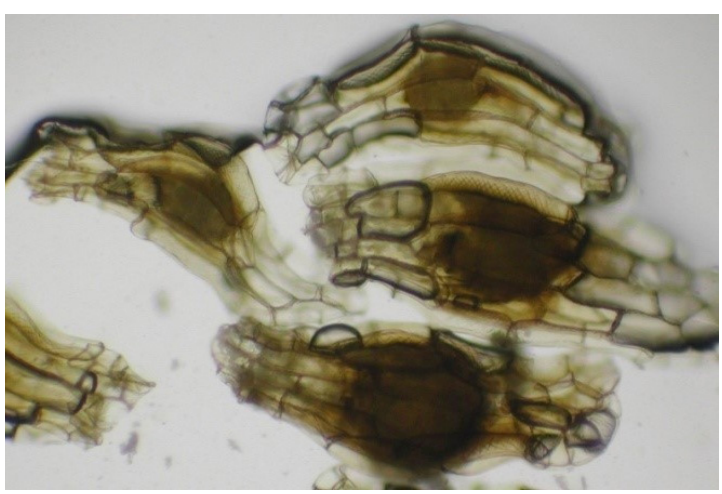

lium klorür (TTC) (Warghat et al., 2014). In this respect, it was treated with $10 \%$ hydrogen peroxide $\left(\mathrm{H}_{2} \mathrm{O}_{2}\right)$ for 60 minutes for counting the embryocontaining seeds. After the seed coat became partially transparent, the seeds containing the embryo were counted under the Stereo Microscope (Fig.1). The structure of the seed coat is important for germination. For this reason, the Scanning Electron Microscope (SEM) was used to determine the testa structure of the seeds.

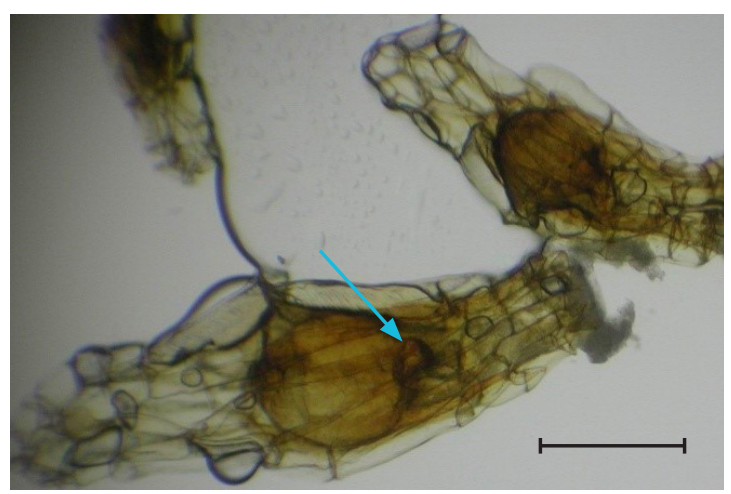

Figure 1. $H$. robertianum (left) and $O$. italica (right) treated with hydrogen peroxide $\left(\mathrm{H}_{2} \mathrm{O}_{2}\right)$. Their embryos and suspensor (Scale bar $100 \mu \mathrm{m})$

Şekil 1. Hidrojen peroksit $\left(\mathrm{H}_{2} \mathrm{O}_{2}\right)$. ile muamele edilmiş $H$. robertianum (sol) ve $O$. italica (sağ) tohumlarında embriyo ve suspensör (ölçek $100 \mu \mathrm{m})$

\subsubsection{Seed moisture content}

Seed moisture content is technically difficult to determine accurately since orchid seeds are so light, but a few data exist (Rasmussen, 1995). In the study, $H$. robertianum and $O$. italica seeds were stored in Eppendorf tubes after being air-dried. To determine the moisture content of orchid seeds, the temperature of moisture detection device ( $\mathrm{Ra}$ dwag MA 50.R) was adjusted to $50{ }^{\circ} \mathrm{C}$ and moisture contents were determined in $\%$. Our studies for determining seed moisture were carried out in six replications.

\subsubsection{Plant and tuber properties}

Plants grown in their natural environment have been used to determine plant length, tuber size and weights. Plants with tubers removed are planted again in nursery to produce new tubers.

\subsubsection{Statistical analysis}

Data were subjected to analysis of variance (ANOVA) and means were compared by Duncan's multiple range test at $\mathrm{P}<0.05$ using the SPSS (IBM SPSS ver 21).

\section{Results and Discussion}

\subsection{Plant and tuber properties}

\subsubsection{H. robertianum}

In our study, $H$. robertianum was found mostly in oliveyards that have not been tillage for a long time. İt is mainly developed in clearings of forest formations $(60 \%)$, followed by grasslands and nitrophilous pastures $(29 \%)$, shrublands $(11 \%)$ up to 1700m (Delforge, 2006; Gutiérrez et al., 2018) and generally seen alkaline meadows, calcareous hillsides, chalk or limestone, open grassy rocky slopes, Pinus and Quercus woodland, macchie, phrygana. (Davis, 1984; Rasmussen, 1995; Rossi, 2002; Parlak and Tutar, 2012). H. robertianum is distributed throughout the Mediterranean basin, from the Balkans to Iberia and the Maghreb. It is reported that generally found in open areas, pine and oak forests and maquis spaces, between olive groves and abandoned fields (Aedo and Herrero, 1986; Altundağ et al., 2012). Although it is spread over a wide area in countries around the Mediterranean, it is a very rare species (Delforge, 2006). It is not endemic but has vulnerable (VU) category (Bongers, 1993; Sezik et al., 2007). Both species (H. robertianum and $O$. italica) are strictly protected by "The Convention on International Trade in Endangered Species of Wild Fauna and Flora" (CITES) convention (Dulıć et al., 2018). 
In our study, the average plant height was measured as $27.6 \mathrm{~cm}$. It was observed that $H$. robertianum in the shade was taller (Fig. 2). Altundağ et al. (2012) reported that the average height of $H$. robertianum was measured as $49.6 \mathrm{~cm}$ but habitat conditions may cause plant height to differ. Aedo and Herrero, (1986) determined the high of plants between 30$80(100) \mathrm{cm}$ in $H$. robertianum. In our study, the average tuber length was $59 \mathrm{~mm}$, and the tuber width was measured as $40 \mathrm{~mm}$ and the average tuber weight was found to be $18.6 \mathrm{~g}$ (Fig. 2). In the study by Altundağ et al. (2012), the average tuber length was determined as $37.6 \mathrm{~mm}$ and the tuber width as $28.6 \mathrm{~mm}$. Aedo and Herrero (1986) give the tuber size $23-50 \mathrm{~mm} \times 14-44 \mathrm{~mm}$.
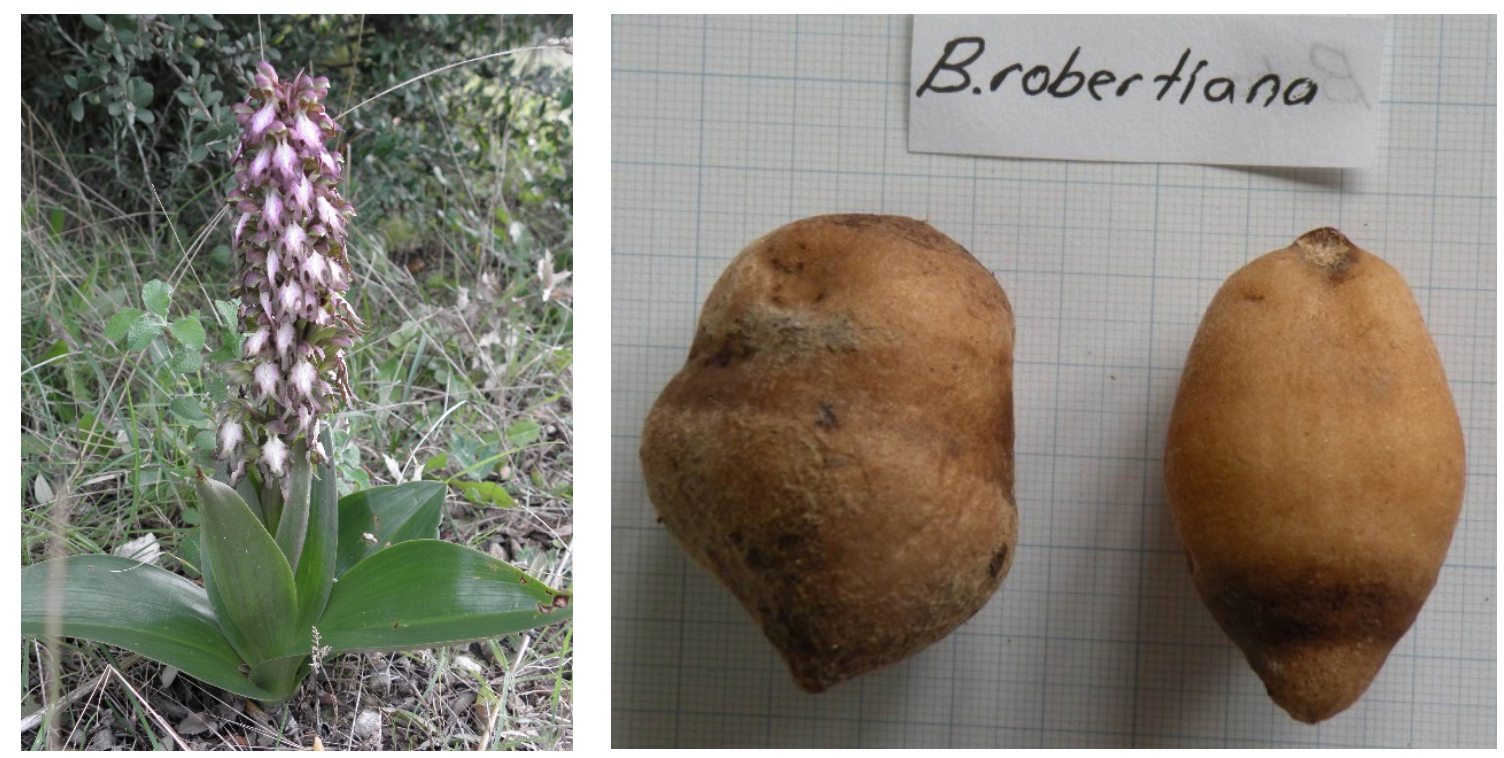

Figure 2. H. robertianum (synonymous Barlia robertiana) flower stalks and tubers Şekil 2. H. robertianum (sinonim Barlia robertiana) çiçek kurulu ve yumruları

H. robertianum is one of the first blooming species and it has been seen to bloom in February- April. Renz and Taubenheim (1984) and Delforge (2006) reports that it blooms in April- January.

\subsubsection{O. italica}

O. italica is one of the least common species during field studies. It has been observed that it generally spreads within the macchie and lime soils where grazing is not done. The tuber size of species attracts collectors (Parlak and Tutar, 2012). O. italica is generally found growing in pine forests, poor grassland, open garrigue, scrub, woodland edges, open woodland and shrubby, mostly evergreen coastal vegetation, macchie, grassy places, usually in full sun on calcareous soil. It can form a large colony and grow 20-50 cm. (Davis, 1984; Rossi, 2002; Delforge, 2006; Johnson, 2010). Aedo and Herrero (1986), on the other hand, reports plant height on average $18-43(50) \mathrm{cm}$. In our study the average plant length was measured as $24.5 \mathrm{~cm}$, tuber length was $31 \mathrm{~mm}$, and tuber width was measured as $26 \mathrm{~mm}$. Aedo and Herrero (1986) determined their tuber size as $15-37$ $\mathrm{mm} \times 7-30 \mathrm{~mm}$. The average tuber weight was determined as $12.3 \mathrm{~g}$ in our study (Fig. 3).
Sezik (1984) reported the plant blooms in late March and April. It is one of the rare species.

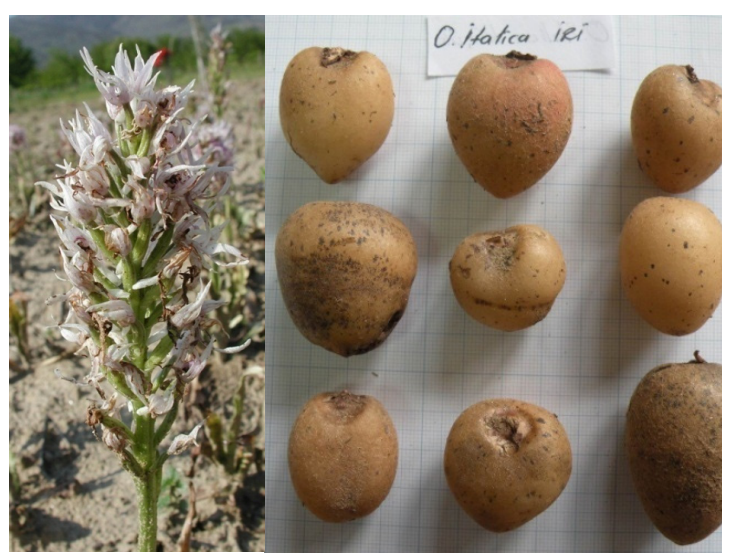

Figure 3. O. italica flower stalks and tubers Şekil 3. O. italica çiçek salkımı ve yumruları

\subsection{Seed properties and empty seed formation}

\subsubsection{H. robertianum}

In this study, the length and thickness of the seeds was determined in SEM microscope. Average seed 
length in $H$. robertianum was found $528 \mu \mathrm{m}$ and thickness was $145 \mu \mathrm{m}$ (Fig. 4). Szendrák (1997), also determined that the length varies between 460 $\mu \mathrm{m}-520 \mu \mathrm{m}$ and $135 \pm 25 \mu \mathrm{m}$ and the median cell length is $150 \mu \mathrm{m}$. Aybeke (2014) reported that 531 $\pm 54 \mu \mathrm{m}$ in length and $135 \pm 25 \mu \mathrm{m}$ in width $H$. robertianum seeds are fusiform in shape, transparent and on the periclinal walls transversal reticulations are present.

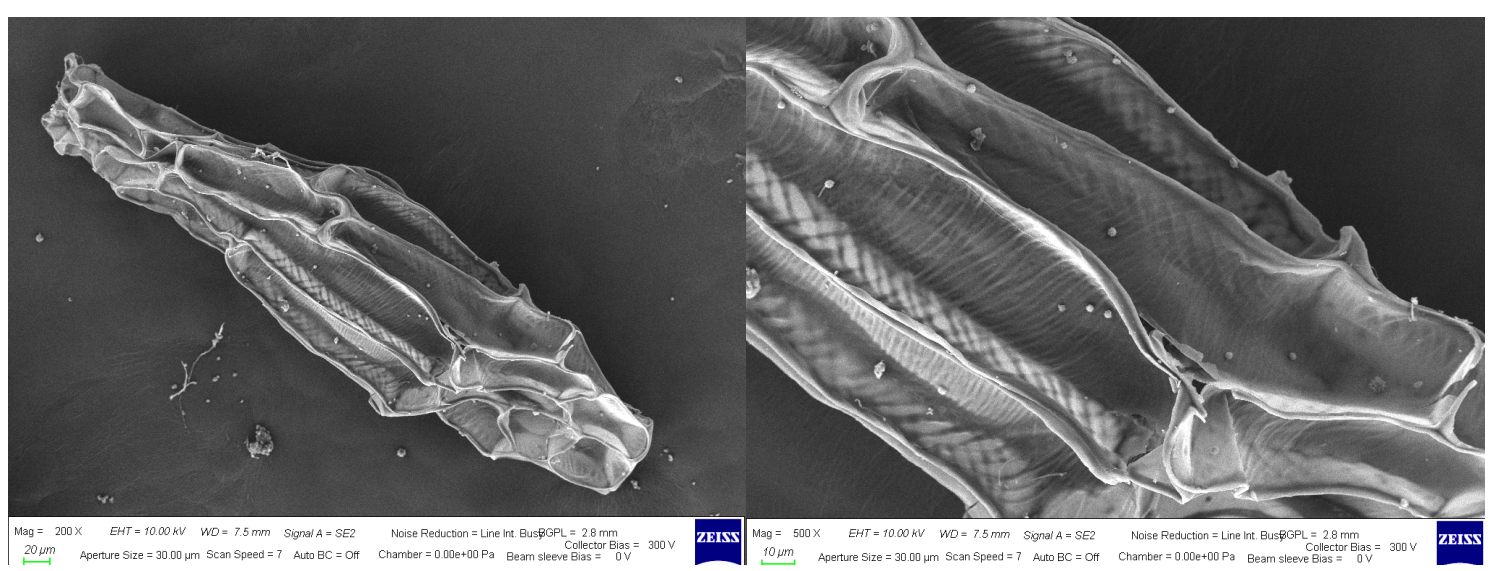

Figure 4. Seed and seed coat under Scanning Electron Microscopy (SEM). Scanning electron micrographs of $H$ robertianum seed (left). Seed surface with longitudinal cells ( $200 \mathrm{x}$ magnification; scale bar $=20 \mu \mathrm{m})$, (right). Anticlinal and smooth periclinal walls of testa cell (500 x magnification; scale bar $=10 \mu \mathrm{m})$

Şekil 4. H. robertianum tohum ve tohum kabuğunun Taramalı Elektron Mikroskopunda (SEM) görünümü. (sol). Kabuk yapısının longitudinal görünümü (büyütme $200 \mathrm{x}$; ölçek $=20 \mu \mathrm{m}$ ), (sağ). Tohum kabuğunun anticlinal ve periclinal duvarlarının görünümü (büyütme $500 \mathrm{x}$; ölçek=10 $\mu \mathrm{m}$ )

\subsubsection{O. italica}

Length and thickness measurements were made. The seed length of this species is $468 \mu \mathrm{m}$ and thick- ness is $143 \mu \mathrm{m}$ (Fig. 5). The seed length was 276.66 $\mu \mathrm{m} \pm 40.20 \mu \mathrm{m}$ while the seed thickness was determined as $120.33 \mu \mathrm{m}$ by Gamarra et al. (2012).

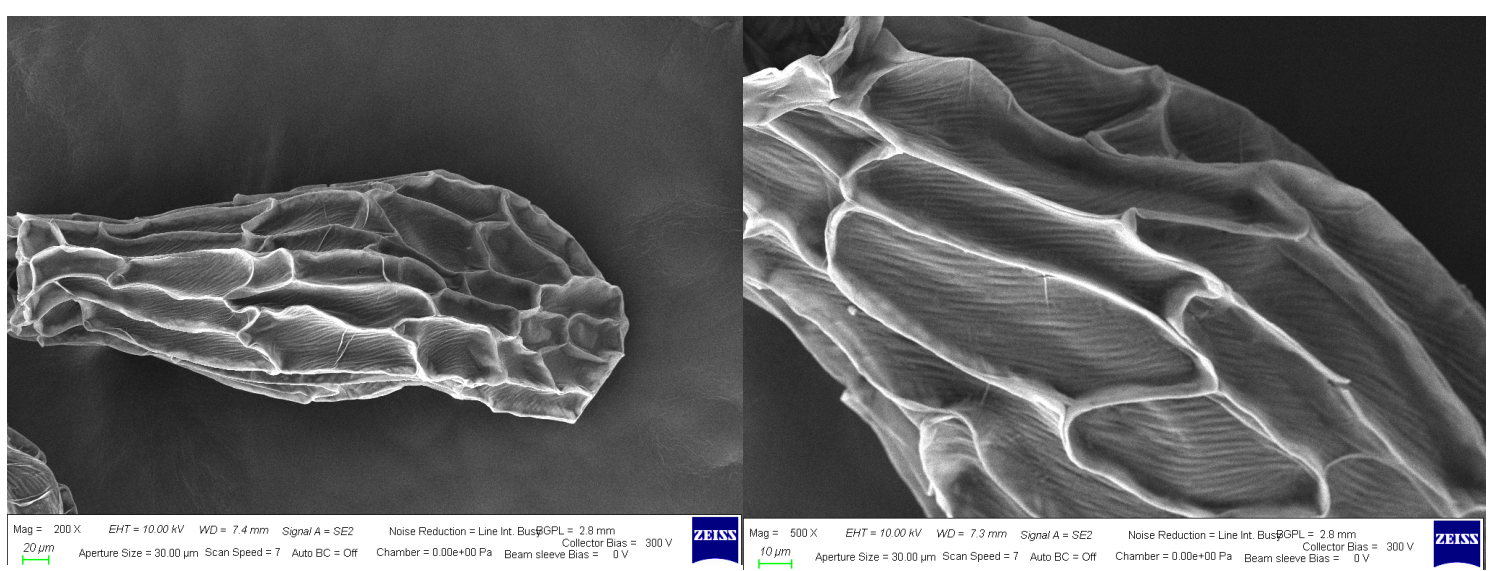

Figure 5. Seed and seed coat under Scanning Electron Microscopy (SEM). Scanning electron micrographs of $O$. italica seed (left). Seed surface with longitudinal cells ( $200 \mathrm{x}$ magnification; scale bar $=20 \mu \mathrm{m})$, (right). Anticlinal and smooth periclinal walls of testa cell (500 x magnification; scale bar $=10 \mu \mathrm{m})$

Şekil 5. O. italica tohum ve tohum kabuğunun Taramalı Elektron Mikroskopunda (SEM) görünümü (sol). Kabuk yapısının longitudinal görünümü (büyütme $200 \mathrm{x}$; ölçek $=20 \mu \mathrm{m}$ ), (sağ). Tohum kabuğunun anticlinal ve periclinal duvarlarının görünümü (büyütme $500 \mathrm{x}$; ölçek=10 $\mu \mathrm{m}$ )

\subsection{Empty seed percentages and reasons}

\subsubsection{Habitat fragmentation}

Seed rate without embryo was determined as $36 \%$ in $H$. robertianum and $49 \%$ O. italica. These rates are high in terms of empty seed formation. At this low level of seed set, excessive destruction effects due to the physical properties of both species, high glucomannan content (Türkmen, 2019) and high tuber weight. The fruit set was not found to be si- 
milar in all of the presently studied species and it ranged between $60 \%$ and $90 \%$ in the majority of cases (Verma et al, 2014).

Due to its early flowering, easy view, large tubers, dug very early and excessively destroyed. In our field studies, $H$. robertianum and $O$. italica were rarely encountered and their fragmented habitats were observed due to excessive harvesting. One drawback of this extreme destruction in orchids is that, due to habitat fragmentation, populations and individuals are separated from each other. This situation brings pollination and fertilization problems with it. According to Slaviero (2016) and Fantinato et al. (2018), the main reasons for habitat fragmentation are surrounded by woodland, areas under cultivation, villages and industrialised areas and over harvesting.

According to Ghorbani et al. (2014), current harvesting practices are too destructive and early harvesting prevents seed set and dispersal. In studies conducted on this subject, information is available that disintegrated habitats prevent pollination and fertilization and reduce seed quality and reproductive success. (Aguirre and Dirzo, 2008; Jacquemyn and Brys, 2015; Fantinato et al., 2019). Interspecies interbreeding is increasing as habitat fragmentation makes populations smaller and isolated (Angeloni et al., 2011; Pierce and Belotti, 2011), which often results in reduced reproduction and offspring survival (Charlesworth and Charlesworth, 1987; Keller and Waller, 2002; Lienert, 2004). Habitat fragmentation can lead to population declines and change in foraging behavior by limiting the movement of pollinating insects (Aguirre and Dirzo, 2008; Fantinato et al., 2019). This is probably why small and isolated populations visit fewer pollinators and receive less pollen loads, which can result in problems such as reduced pollen transport, reduced reproductive success and poor seed quality (Jacquemyn and Brys, 2015).

\subsubsection{Nectarless flower formation and effects on pollination}

Empty seed rate was higher in O. italica (49\%) than $H$. robertainum $(36 \%)$. It is seen that the embryo does not occur even though the testa of many seeds is formed (Fig. 6). Whether nectar is present in sahlep orchids is a factor affecting pollination and seed formation. It can be said that in the empty seed formation, these species do not attract insects and bees because of their nectarlessness and there is a pollination problem. Therefore, nectarless orchids are more fragile and sensitive to environmental changes. According to Pierce and Belotti, (2011) and Claessens and Kleynen, (2016) many orchids produce nectar to attract insects. However, in the European orchids, there is a considerable number of orchids which produce no nectar. However, around 9000 orchid species (36\% of all orchids) worldwide do not produce nectar.

In fertilization, sometimes pollen only touches the stigma, and the egg (ovule) continues to develop, but in this case, seeds that do not contain embryos are formed (Pierce and Belotti, 2011). The rate of encapsulation of nectarless species was $37 \%$, and $74 \%$ of nectar species. Neiland (1994) determined that only $14.3 \%$ of the flowers in $O$. italica constitute seed capsules.

Pollen transfer is mainly carried out by pollinating insects wasps, various bees, bumblebees, butterflies and moths, ants, beetles, hoverflies, flies and nightflying insects (Rossi, 2002; Pierce and Belotti, 2011; Fantinato et al., 2017; Gilián et al., 2018). Himantoglossum species are non-rewarding since there is no evidence of nectar in the spur and they are believed to lure pollinators with a male goat smell (Carey and Farrell, 2002; Fantinato et al., 2017). The pollination system of food deceptive orchids, which do not offer any food reward to their pollinators, is particularly problematic and has been thought to determine a low visitation rate, since pollinators learn to avoid deceptive flowers, resulting in a low fruit set due to pollination limitation (Pellissier et al., 2010). Empty seed formation is more common in genus such as Ophrys or Serapias, which show fraudulent pollination due to the resemblance of a flower to an insect. For instance, Ophrys apifera and O. benacensis, showed signs of fertility problems such as a low proportion of seeds that contained embryos (Pierce and Belotti, 2011). In a study conducted in H. adriaticum, seed set rates were determined to vary between $5 \%$ and $45 \%$ and low germination rates were observed (Bíró et al., 2015).

All other European Himantoglossum species like $H$. robertianum or $H$. adriaticum are also exclusively pollinated by various Hymenoptera (insects) (Claessens and Kleynen, 2016). H. robertianum blooms from early February and earlier than other orchid species. During this period, the air temperature is below $15^{\circ} \mathrm{C}$ and limit insect activity (Argue, 2012a). Since fertilization in Himantoglossums is mostly carried out with insects and Andre$n a$ and Colletes (insects) species and honey bees do not flight early of these species may cause pollination problems and empty seeds. (Rossi, 2002; Fantinato et al., 2017).

It is determined that embryo sizes are different in addition to seed formation without embryos in both types by us (Fig. 6). Full seed formation is due to 
effective pollination (Rasmussen, 1995). The fact that individuals are too far apart or out of reach of pollinator agents may increase the rate of selfpollination and thus empty and small embryo seed formation (Argue, 2012b). In the studies conducted, it was determined that the size and mass of the offspring formed when cross-pollination does not occur (Hill et al., 2006; Spinardi and Bassi, 2012).

Cross-pollination has also been tested for other orchid species (Tremblay et al., 2005; Pierce et al., 2010), demonstrating that orchids that were given supplemental pollination had higher levels of fruit set than those pollinated naturally. In small, isolated populations, genetic flow decreases, while the chances of inbreeding increase, resulting in inbreeding depression (Frankham, 2015). It was determined that cross pollination increased offspring health, fruit set, fruit size and mass (Hill et al., 2006; Spinardi and Bassi, 2012). The detrimental effects of inbreeding can be observed at different developmental stages of the plant (e.g. low production of fruit and viable seed, low total seed production per fruit, high production of empty seeds per fruit), but are usually most pronounced during the germination stage with a low germination rate. Positive results were obtained from artificial pollination studies to solve this problem (Ferdy et al., 2001; Smithson, 2006; Pierce et al., 2010; Sletvold et al., 2012; Hens et al., 2017, Del Vecchio et al., 2019).

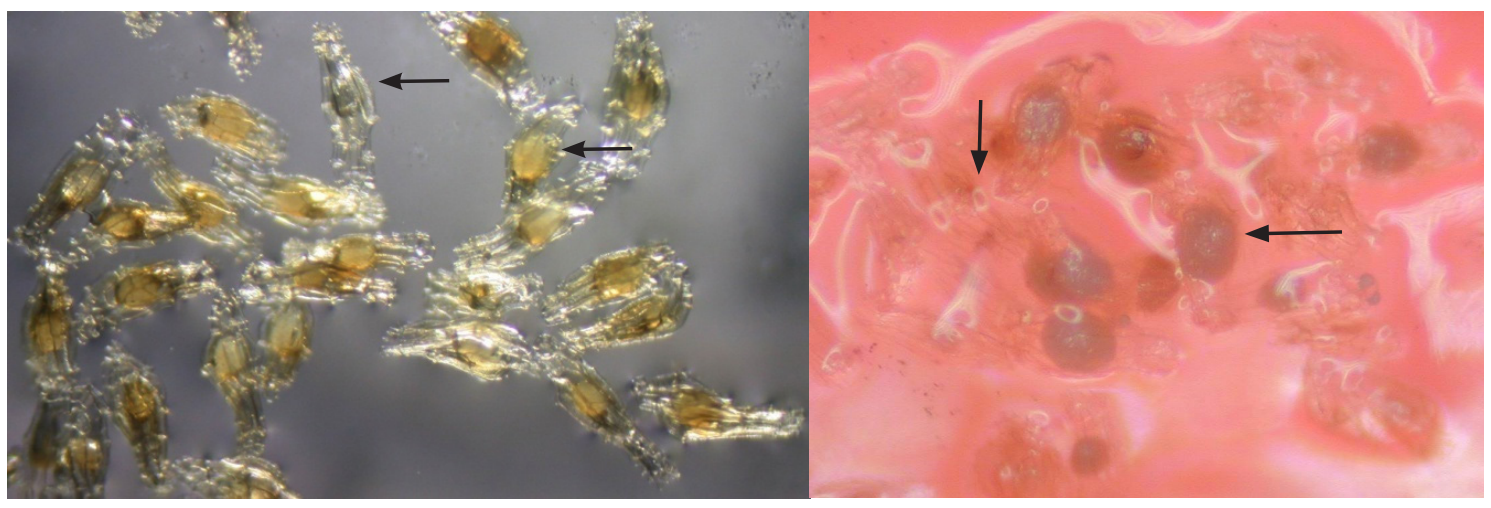

Figure 6. The embryo is visible through the transparent testa under light microscopy. H. robertianum (left) and $O$. italica (right) embryos of different size and non-embryo seed formations

Şekil 6. Şeffaf hale gelen embriyonun 1 şı mikroskobu altında görünümü. H. robertianum (sol) ve O. italica'da (sağ) farklı büyüklüklerdeki embriyolar ve embriyosuz tohum oluşumu

\subsection{Seed moisture}

The average moisture content of the seeds in $H$. robertianum and $O$. italica was found $6.32 \%$ and $5.72 \%$ respectively. These rates are compatible with previous studies. According to Rasmussen (1995), when mature seeds of a range of European species were desiccated over silica gel in a refrigerator and should accordingly have contained about 5\% moisture. In several other species moisture content is found $5 \%$.

\subsection{Seed count and weights}

The number of seeds in a capsule was calculated as 26,500 in $H$. robertianum and 14,700 in O. italica. The number of seeds in $1 \mathrm{~g}$ was determined 1.059 .000 seeds in $H$. robertianum and 1.400 .000 seeds in $O$. italica. One seed weight was calculated as $0.00094 \mathrm{mg}$ in $H$. robertianum and $0.00071 \mathrm{mg}$ in O. italica. Although Orchids seeds are the smallest member of the plant kingdom there is not many studies on weights (Rasmussen, 1995). Johri (1985) reported a seed weight as $0.002 \mathrm{mg}$. Rasmussen (1995) also states that Goodyera repens and Cep- halanthera damasonium seeds are about $2 \mu \mathrm{g}$ (microgram). It is known that the quality of seeds that are formed when cross-pollination does not occur in addition to the increase of empty seed rate in seeds with insufficient pollination and fertilization (Rasmussen, 1995). In our study, H. robertianum seeds were found to be heavier because they had more embryos.

\subsection{Air space in the seeds}

Embryo volume is an important attribute as it directly affects the percentage of available air space inside seed. Since the embryo is very small in orchid seeds, air covers most of the seed (Verma et al, 2014). This is an adaptation that allows the dispersal of the seed with air, and the air volume changes according to the species and the structure of the seed coat. Because of their small size, shape and large air space, orchid seeds can float in the air for long periods For example, free air space in seeds is variable At $8.2 \%$, the free air space in Dactylorchis foliosa is among the smallest, whereas the largest is 99\% in Cattleya (Arditti and Ghani, 2000). 
Most orchid seeds -like $H$. robertianum and $O$. italica -are fusiform and approximate two cones joined at their bases. Therefore their internal volume can be estimated with the formula:

Percent air space $=($ seed volume-embryo volume $) /$ seed volume $\mathrm{x} 100$

Since many orchid seeds are in fusiform shape, the formula $2(\pi / 3 \mathrm{r} 2 \mathrm{~h})$ is used to calculate the seed volume ( $h=1 / 2$ seed length, $r=1 / 2$ seed width).

Since the embryo shapes of $H$. robertianum and $O$. italica are prolate spheroid shaped, $4 / 3 \pi \mathrm{ab}^{2}$ formula is used to find the embryo volume. $(\mathrm{a}=1 / 2$ major axis, $b=1 / 2$ minor axis) (Arditti et al, 1979; Arditti et al, 1980; Arditti and Ghani, 2000). When calculated using these formulas, the air space of $\mathrm{H}$. robertianum was determined $41 \%$ and $O$. italica was $44 \%$ respectively.

Seed and embryo volume in orchids differs from species to species (Arditti et al, 1980). According to Verma et al. (2014), larger seeds have more air space $(82.127-95.650 \%)$. In another study conducted by Hariyanto et al (2020) on Dendrobium species, the percentage of air space in seeds was found to be below 49\%. In the study by Arditti and Ghani (2000) orchids average free air space in testa is determined as $43.01(\%)$.

\section{Conclusion}

Factors such as urbanization, forestry activities, narrowing of agricultural areas, herbicide use, road constructions and habitat fragmentation threaten the life and spread of orchids. Especially in the Mediterranean Basin, the species of sahlep orchids are more threatened than others due to excessive harvesting for food. All these factors disrupt the natural balance in the spread of orchids.

Isolated populations are formed as a result of excessive destruction and habitat fragmentation. This can cause pollination problems. As a result of insufficient pollination, seeds without embryos or small embryos are formed. Embryo-free seed formation was observed more in $O$. italica.

In this study, the most destroyed $H$. robertianum and $O$. italica, which are used in the production of sahlep, have been investigated. Although $\mathrm{H}$. robertianum is one of the most seed setting species, its spread has been observed to be very low due to excessive destruction. Reproduction and preservation of these two species in natural environments should be ensured by producing in vitro. Besides measures should be taken to ensure pollination between fragmented habitats. Protected areas, especially National Parks, are important areas in conserving the extinction of these heavily degraded species and should be included in "Genus conservation Action Plans".

\section{Acknowledgement}

We thank Bursa Technical University, Faculty of Forestry, Department of Forest Engineering for allowing the use of their facilities for this study.

\section{References}

Aedo, C., Herrero, A., 1986. Flora Iberica, Plantas vasculares de la Península Ibérica e Islas Baleares. Vol. XXI, Departamento de Publicaciones del CSIC Vitruvio, Madrid.

Aguirre, A., Dirzo, R., 2008. Effects of fragmentation on pollinator abundance and fruit set of an abundant understory palm in a Mexican tropical forest. Biological Conservation, 141: 375-384.

Altundağ, E., Sevgi, E., Kara., Ö., Sevgi, O., Tecimen, H,B., Bolat, İ., 2012. Himantoglossum robertianum (Lo1sel.) P. Delforge (Orchidaceae) türünün morfolojisi, anatomisi ve yetişme ortamı özellikleri. Türkiye 2. Orkide ve Salep Çalıştayı, Ege Tarımsal Araştırma Enstitüsü Müdürlüğü, p 173, 25-26 Nisan 2012.

Angeloni, F., Ouborg, N.J., Leimu, R., 2011. Meta-analysis on the association of population size and life history with inbreeding depression in plants. Biological Conservation, 144: 35-43.

Arditti J, Michaud JD, Healey P.L., 1979. Morphometry of orchid seeds: I. Paphiopedilum and native California and related species of Cypripedium. Amer J Bot 66: 1128-1137.

Arditti, J., 1967. Factors affecting the germination of orchid seed. Botanical Review, 33: 1-97.

Arditti, J., Ghani, A.K.A., 2000. Numerical and physical properties of orchid seeds and their biological implications. New Phytologist, 145: 367-421.

Arditti, J., M,A., Clements, G., Fast, G., Hadley, G., Nishimura, R. Ernst., 1982. Orchid Seed Germination and Seedling Culture- A manual. In: Orchid Biology- Reviews and Perspectives. Vol. II, Cornell University Press, Ithaca, New York

Arditti, J., Michaud, J. D., \& Healey, P. L. 1980. Morphometry of Orchid Seeds. II. Native California and Related Species of Calypso, Cephalanthera, Corallorhiza and Epipactis. American Journal of Botany, 67 (3), 347-360. https://doi. org/10.2307/2442345.

Argue, C.L., 2012a. The Pollination Biology of North American Orchids: Volume 1, North of Florida and Mexico, Springer, New York.

Argue, C.L., 2012b. The Pollination Biology of North American Orchids: Volume 2 North of Florida and 
Mexico, Springer, New York.

Aybeke, M., 2014. Morphological and histochemical investigations on Himantoglossum robertianum (Loisel.) P. Delforge (Orchidaceae) seeds. Plant Systematics Evolution, 300 (1): 91-97, Doi 10.1007/s00606-013-0862-2.

Baskin, C.C., Baskin, J.M., 2014. Seeds, Ecology, Biogeography, and Evolution of Dormancy and Germination. Academic Press, San Diego.

Bíró, E., Bód1s, J., Nagy, T., Tökölyı, J., Molnár, V., 2015. Honeybee (Apis mellifera) mediated increased reproductive success of a rare deceptive orchid. Applied Ecology Environmental Research, 13: 181-192.

Bongers, W., 1993. Überführung asymbiotisch vermehrter terrestrischer orchideen in "natürliche" Kultursubstrate. Erschienen in die Orchidee, 44(6): 302-304.

Carey, P.D., Farrell, L., 2002. Himantoglossum hircinum (L.) Sprengel. Journal of Ecology, 90:206-218.

Charlesworth, D., Charlesworth, B., 1987. Inbreeding depression and its evolutionary consequences. Annual Review of Ecology and Systematics, 18: 237-268.

Claessens, J., Kleynen, J., 2016. The pollination of European orchids, Part 5: Himantoglossum and Anacamptis, Two examples of deceptive pollination. Journal of Hard Orchid Society, Vol. 13 No.4 (82).

Davis, P.H., 1984. Flora of Turkey and East Aegean Islands. Vol.8. Edinburgh at the University Press, Edinburgh.

De, L.C., Pathak, P., Rao, A.N., Rajeevan, P.K., 2014. Commercial Orchids. Published by De Gruyter Open Ltd, Warsaw/Berlin.

Del Vecchio, S., Pierce, E., Fantinato, G., Buffa, G., 2019. Increasing the germination percentage of a declining native orchid (Himantoglossum adriaticum) by pollen transfer and outbreeding between populations. Plant Biology, 1-7, Doi: 10.1111/plb/.12986.

Delforge, P., 2006. Orchids of Europe, North Africa and the Middle East. Timber Press, Portland.

Doijode, S.D., 2001. Seed Storage of Horticultural Crops. Food Products Press, New York, London.

Dulıć, J., Ljubojević, M., Prlaınović, I., Barać, G., Narandžıć, T., Ognjanov, V., 2018. Germination and protocorm formation of Ophrys sphegodes MILL. - In Vitro protocol for a rare orchid species. Contemporary. Agriculture, 67 (3-4): 196-201.

Dutra, D., Johnson, T.R., Kauth, P.J., Stewart, S.L., Kane, M.E., Richardson, L., 2008. Asymbiotic seed germination, in vitro seedling development, and greenhouse acclimatization of the threatened terrestrial orchid Bletia purpurea. Plant Cell, Tissue and Organ Culture, 94: 11-21.

Fantinato, E., Del Vecchio, S., Baltieri, M., Fabris, B.,
Buffa, G., 2017. Are food-deceptive orchid species really functionally specialized for pollinators? Ecological Research, 32: 951-959.

Fantinato, E., Del Vecchio, S., Gaetan, G., Buffa, G., 2019. The resilience of pollination interactions: importance of temporal phases. Journal of Plant Ecology, rty005, Doi.org/10.1093/jpe/rty005. FAO (2014) Genebank standards for plant genetic resources for food and agriculture, Revised edn. Italy, Rome.

Fantinato, E., Del Vecchio, S., Giovanetti, M., Acosta, A.T.R., Buffa, G., 2018. New insights into plant coexistence in species-rich communities: the pollination interaction perspective. Journal of Vegetation Science, 29: 6-14.

Ferdy, J.B., Loriot, S., Sandmeier, M., Lefranc, M., Raquin, C., 2001. Inbreeding depression in a rare deceptive orchid. Canadian Journal of Botany, 79: 1181-1188. Doi: 10.1139/cjb-79-10-1181.

Frankham, R., 2015. Genetic rescue of small inbred populations: Meta-analysis reveals large and consistent benefits of gene flow. Molecular Ecology, 24: 2610-2618. Doi: $10.1111 / \mathrm{mec} .13139$.

Gamarra, R., Ortunez, E., Cela, P.G., Guadano, V., 2012. Anacamptis versus Orchis (Orchidaceae): seed micromorphology and its taxonomic significance. Plant Systematics Evolution, 298:597-607, Doi 10.1007/s00606011-0569-1.

Ghorbani, A., Gravendeel, B., Zarre, S., Boer, H.D., 2014. Illegal wild collection and international trade of CITES-listed terrestrial orchid tubers in Iran. Traffic. 26 (2), 52 .

Gilián, L.D., Judit, B., Eszeki, E., Illyes, Z., Biro, E., Nagy, J.G., 2018. Germination traits of Adriatic lizard orchid (Himantoglossum adriaticum) in Hungary. Applied Ecology Environmental Research, 16 (2): 1155-1171, Doi: 10.15666/aeer/1602-11551171.

Gutiérrez, I.R., Labarga, J.M.M., Díaz, J.A., Castro, A.G.F., Saiz, J..CM., 2018. Expansion of Himantoglossum robertianum (Orchidaceae) in Madrid: a case study on environmental variables and geographical distribution. Mediterranean Botany, 39 (2) 2018: 111-117, http:// dx.Doi.org/10.5209/MBOT.60081.

Hariyanto, S., Pratiwi, I.A., Utami, E.S.W., 2020. Seed Morphometry of Native Indonesian Orchids in the Genus Dendrobium. Scientifica. Volume 2020/06 https:// doi.org/10.1155/2020/3986369

Hens, H., Pakanen, V.M., Jäkäläniemi, A., Tuomi, J., Kvist, L., 2017. Low population viability in small endangered orchid populations: genetic variation, seedling recruitment and stochasticity. Biological Conservation. 210: 174-183. https://Doi.org/10.1016/j. biocon.2017.04.019.

Hill, N.M., Myra, M.T.D., Johnston, M.O., 2006. Breeding system and early-stage inbreeding depression in 
a Nova Scotian population of the global rarity, Sabatia kennedyana (Gentianaceae). Rhodora 108: 307-328.

Jacquemyn, H., Brys, R., 2015. Pollen limitation and the contribution of autonomous selfing to fruit and seed set in a rewarding orchid. American Journal of Botany, 102 (1): $67-72$.

Johnson, L., 2010. Orchids. First published in the United States in 2010 by DK Publishing, New York.

Johri, B.M., 1985. Comparative Embryology of Angiosperms, Springer-Verlag, Berlin.

Keller, L.F., Waller, D.M., 2002. Inbreeding effects in wild populations. Trends in Ecology \& Evolution, 17: 230-241.

Lienert, J., (2004) Habitat fragmentation effects on fitness of plant populations - a review. Journal for Nature Conservation, 12: 53-72.

Maheshwari, R., 2005. Fungi-Experimental Methods in Biology. Taylor \& Francis Group, Boca Raton.

Miyoshi, K., Mii, M., 1998. Stimulatory effects of sodium and calcium hypochlorite, pre-chilling and cytokinins on the germination of Cypripedium macranthos seed in vitro. Physiologia Plantarum, 102: 481-486.

Molnár, A.V., Nagy, T., Löki, V., Süveges, K., Takács, A., Bódis, J., Tökölyi, J., 2017. Turkish graveyards as refuges for orchids against tuber harvest. Ecology and Evolution, 2017: 1-8, Doi: 10.1002/ece3.3562.

Neiland, M.R.M., 1994. Reproductive Ecology of British and Mediterranean Orchids.-December 1994, Presented at the University of Aberdeen for the degree of Doctor of Philosophy, $325 \mathrm{pp}$.

Parlak, S., Tutar, M., 2012. Some Soil Properties of The Most Collected Salep Orchids in Karaburun Peninsula. Turkey. 2. Orchids and Sahlep Workshop, April 25 to 26, 2012, Menemen İzmir.

Pellissier, L., Vittoz, P., Internicola, A., Gigord, L.D.B., 2010. Generalized food-deceptive orchid species flower earlier and occur at lower altitudes than rewarding ones. Journal of Plant Ecology, volume 3:number 4: 243-250.

Pierce, S., Belotti, J., 2011. The conservation of terrestrial orchids: from the Alps to the Po Plain of Lombardy, Parco delle Orobie Bergamasche and the Centro Flora Autoctona della Regione Lombardia. The Native Flora Centre, Milan.

Pierce, S., Ferrario, A., Cerabolini, B., 2010. Outbreeding and asymbiotic germination in the conservation of the endangered Italian endemic orchid Ophrys benacensis. Plant Biosystems, 144: 121-127.

Rasmussen, H.N., 1995. Terrestrial Orchids; From Seed to Mycotrophic Plant. Cambridge University Press, Cambridge.

Renz, J., Taubenheim, G., 1984. Orchidaceae flora of
Turkey and East Aegean Islands. V.8 (P.H.Davis, R.Mill, K. Tan, eds.), Published by University Press, Edinburgh.

Rossi, W.,. 2002. Orchidee d'Italia. Quad. Cons. Natura, 15, Min. Ambiente - Ist. Naz. Fauna Selvatica.

Sezik, E., 1984. Orkidelerimiz. Sandoz Kültür Yayınlar1, İstanbul.

Sezik, E., 2002. Turkish orchids and salep. Acta Pharmaceutica Turcica, 44: 151-157.

Sezik, E., İşler, S., Orhan, Ç., Deniz, G.İ., Güler, N., Aybeke, M., Üstün, O., 2007. Salep ve Orkidelerin Tahribi. TÜBİTAK Araştırma Projesi. Proje No: TBAG-Ç. SEK/23(103T008). Ankara.

Slaviero, A., 2016. Use of Lignin Modifying Enzymes (LMEs) to Aid Orchid Seed Germination, PhD Thesis, Scuola Dottorale di Ateneo Graduate School.

Sletvold, N., Grindeland, J.M., Zu, P.J., Agren, J., 2012. Strong inbreeding depression and local outbreeding depression in the rewarding orchid Gymnadenia conopsea. Conservation Genetics, 13:1305-1315. Doi:10.1007/ s10592-012-0373-7.

Smithson, A., 2006. Pollinator limitation and inbreeding depression in orchid species with and without nectar rewards. New Phytologist, 169: 419-430.

Spinardi, A., Bassi, D., 2012. Olive fertility as affected by cross-pollination and boron. The Scientific World Journal, 2012: 375631, 1-8 pp.

Szendrák, E., 1997. Asymbiotic in Vitro Seed Germination, Micropropagation and Scanning Electron Microscopy of Several Temperate Terrestrial Orchids (Orchidaceae). PhD Thesis, The Graduate College at the University of Nebraska.

Tekinşen, K. K., Güner, A., 2009. Kahramanmaraş Yöresinde Yetişen Saleplerin Kimyasal Bileşiminin ve Bazı Fizikokimyasal Niteliklerinin Araştırılması. Selçuk Üniversitesi Bilimsel Araştırma Projeleri, Proje No: 06401061, Konya.

Tremblay, R.L., Ackerman, J.D., Zimmerman, J.K., Calvo, R.N., 2005. Variation in sexual reproduction in orchids and its evolutionary consequences: a spasmodic journey to diversification. Biological Journal of the Linnean Society, 84 (1):1 - 54, Doi: 10.1111/j.10958312.2004.00400.x.

Türkmen, N., 2019. Bazı Yabani Orkide Türlerinden Elde Edilen Saleplerin Maraş Usulü Dondurma Üretiminde Kullanım Olanaklarının Araştırılması. (PhD Thesis), Ankara Üniversitesi Fen Bilimleri Enstitüsü.

Verma, J., Sharma, K., Thakur, K., Sembi, J.K., Vij, S.P., 2014. Study on seed morphometry of some threatened Western Himalayan orchids. Turkish Journal of Botany, 38: 234-251, doi:10.3906/bot-1307-14.

Veyret, Y., 1974. Development of the Embryo and the Young Seedling Stages of Orchids. In: Withner CL (ed) 
The Orchids: Scientific Studies. Wiley, New York.

Warghat, A.R., Bajpa, P.K., Srivastava, R.B., Chaurasia, O.P., Chauhan, R.S., Sood, H., 2014. In vitro protocorm development and mass multiplication of an endangered orchid, Dactylorhiza hatagirea. Turkish Journal of Bo- tany, 38: 737-746 Doi:10.3906/bot-1308-48.

Weston, P.H., Perkind., A.J., Entwisle, T.J., 2005. More than symbioses: orchid ecology with examples from the Sydney Region. Cunninghamia 9: 1-15. 